\title{
MAPPING THE MANTLE LITHOSPHERE FOR DIAMOND POTENTIAL
}

\author{
$\underline{\text { Snyder DB*1 }}$, Bostock MG 2 , \& Lockhart GD 3 \\ ${ }^{1}$ Geological Survey of Canada, Ottawa \\ ${ }^{2}$ Dept. of Earth \& Ocean Sciences, University of British Columbia, Canada \\ $3_{\text {BHP-Billiton, BHP Diamonds, Inc., Canada }}$
}

Diamond deposits are typically identified in four stages: (1) regional targeting in which a region's potential is assessed, often by grid till sampling for indicator minerals or global seismology; (2) kimberlite detection in which till sampling and high resolution aeromagnetic surveys locate individual deposits; (3) deposit delineation in which drill hole core sampling determines a specific deposit's volume and lithology; and (4) evaluation in which bulk sampling establishes a deposit's worth and its feasibility to be mined. Results from the past few decades indicate that globally, for every 1000 candidate magnetic anomalies identified, 100 are kimberlites, ten contain gem-quality diamonds and one is economic to mine in Canada's North. The diamond exploration industry needs discriminating tools to reduce risks at all of these stages. Seismic techniques can provide 3-D maps of key physical properties in the mantle to $700 \mathrm{~km}$ depth to help accomplish stage 1 (Nolet et al., 1994; Bostock, 1999). These results can then be used in conjunction with conductivity maps derived from magneto-telluric soundings and 'ground truth' of actual rock types provided by rare xenolith samples from kimberlites. At present our efforts are concentrated in the central Slave craton of the NWT, Canada, because of the strong geological, geophysical and logistical base currently available. Once a velocity/property model is established in the Slave craton, this innovative, 1st-order exploration tool can be applied throughout Canada and globally.

\section{TELESEISMIC METHODS}

Seismic methods applied to the delineation of Earth structure fall into two broad categories: transmission or travel-time studies and scattered wave studies. Logistically, methods divide into those using single, independent stations recording many distant (teleseismic) earthquakes and those using an array of stations that all record the same seismic wave source, be it teleseismic or man-made. Each method used provides a different feature or characteristic of the velocity model, for example: bulk $\mathrm{P}$-wave or S-wave velocities, depths and geometries of discontinuities, direction of fabric or anisotropy. In remote, harsh environments such as the central Slave craton, it is prudent to begin with single station studies, assess the results and then develop arrays of stations in key areas. Two single station methods are currently being applied in the Slave and their results assessed.

Four years of recording global earthquakes using a few broadband seismometers located near the Ekati diamond mine can be analyzed by the independent SKS-anisotropy and receiver-function techniques to reveal information about layered structured within the mantle of the central Slave craton. Within the past 18 months, 18 POLARIS satellite-telemetry stations have supplemented previous work done using stations with interchangeable hard-disc technology operated by the GSC and a more regional survey done in 1996-98 (Bank et al., 2000).

\section{DisCONTINUITY DETECTION}

The first method applied to data from independent stations is the so-called receiver function method in which source-deconvolved P-to-S converted waves arriving from multiple teleseismic earthquakes reveal discontinuities in seismic wave velocities or density below each seismic station (e.g. Bostock, 1998, 1999). Changes in velocity, density or anisotropy within the mantle scatter upcoming seismic waves and partially convert P-waves into S-waves to reveal the discontinuities. Traditionally, the sharp (to seismic waves with wavelengths of a few $\mathrm{km}$ ) increase in both velocity and density with depth at the Moho (roughly the base of the crust) is the most prominent of these discontinuities. Within the central Slave craton, Moho depth varies between 36 and $42 \mathrm{~km}$ (Figure 1).

Other prominent discontinuities at 85-100 and 140-150 $\mathrm{km}$ depths observed on the transverse components at multiple stations indicate that a layer of low velocity or distinct anisotropy exists between these depths. In the SW Slave near Yellowknife, similar discontinuities were 
observed at nominal depths of 75,135 and $190 \mathrm{~km}$ (Bostock, 1998). The shallowest of these is most clearly defined and comprises a sharp-topped layer $10 \mathrm{~km}$ thick that exhibits $5 \%$ S-wave anisotropy. All three discontinuities were interpreted as underthrust or underplated blocks of Archean crust.

\section{LAYERED ANISOTROPY}

A second method applied to data from independent stations estimates regional-scale fabric or layering within the mantle using differential travel times of S-waves caused by seismic anisotropy arising from the preferred fabric orientations. Seismic waves that travel through the Earth's core as P-waves before converting to S-waves, socalled SKS and SKKS phases, are particularly useful for anisotropy studies (Silver, 1996, is a useful review). Typically, months of data are analyzed in order to produce an average anisotropy measurement for each station, but observations made over two or more years often provide much additional and valuable information.

The variations in the arrival of SKS phases with earthquake azimuth (direction at which seismic wave arrives) reveal patterns that can be modeled by multiple or dipping layers of anisotropy (Vinnik et al., 1992; Rümpker and Silver, 1998; Savage 1999). The observed azimuthal variation at stations within the central Slave can be most easily modeled by assuming two distinct layers of anisotropy within the lithosphere. Considering the discontinuities discussed above, the lower layer probably lies deeper than $150 \mathrm{~km}$ in the mantle and the anisotropy aligns with both North American plate motion and the strike of mantle structures identified by previous geochemical analyses, at $\sim \mathrm{N} 50^{\circ} \mathrm{E}$. The upper layer is more varied and is hypothesized to relate partly to regional fold structures in the crust or to a conductive layer identified in the uppermost mantle between 90 and $150 \mathrm{~km}$.

\section{LAYER INTERPRETATION}

The upper layer and its bounding discontinuities coincide with a prominent regional conductor identified by recent magneto-telluric studies (Jones et al., 2001), but also with an ultra-depleted harzburgite layer identified from studies of garnets extracted from xenoliths in kimberlite core (Griffin et al., 1999; Kopylova and Russell, 2000). The 95- and $145-\mathrm{km}$ discontinuities are not typical of cratons globally although the 'Hales' discontinuity (Hales, 1969) is commonly found at $60-80 \mathrm{~km}$ depths and the 'Lehman' discontinuity (Lehman, 1955) appears beneath continents at $\sim 220 \mathrm{~km}$ depth (Bostock, 1999, and references therein).
The latter has been hypothesized as the base of an anisotropic layer below which aligned textures in peridotite are annealed and thus made more isotropic; it may represent the base of the lithosphere.

The underthrust or subducted layers inferred beneath Yellowknife may extend NW into the central Slave. Alternatively, the central Slave may be underlain by an older $(2.6 \mathrm{Ga})$ convergent zone. The seismic results aid us in constructing a NW-SE cross section of the Slave craton from the surface to $700 \mathrm{~km}$ depths and relate it to surface geology and other geophysical and petrological constraints on mantle composition. It appears significant that major discontinuities are associated with changes in anisotropy more often than with increases or decreases in velocity or density with depth. The change in anisotropy at $95 \mathrm{~km}$ depth correlates with increased conductivity that has been associated with increased graphite content or connectivity (Jones et al., 2001). The change in anisotropy at $145 \mathrm{~km}$ depth correlates with an increase of metasomatism in mantle xenoliths. It is not clear at present if these discontinuities represent the (dis)appearance of anisotropy or just systematic reorientations of anisotropic mantle structure. It is the combined use of the two methods described here that provides powerful constraints on mantle structure, constraints not used in previous interpretations of mantle structure to our knowledge (but see Oreshin et al., 2002).

More precise definition of layers with increased carbon content or metasomatism has direct relevance to mapping potential source regions and long-term mantle reservoirs of diamonds. Once a mantle stratigraphy is established and understood in terms of its seismic and other characteristics, its lateral extent can be mapped. If mantle layers observed here derive from large-scale tectonic events, the resulting improved understanding of a region's geological history from surface mapping and related geochemical and geochronological studies will also aid exploration models and strategies.

Continuing recording of earthquakes at the current 18 POLARIS stations and the infilling of the current array with additional stations will enable other techniques such as travel-time tomography and Kirchoff migrations to provide more continuous $2-\mathrm{D}$ and 3-D images of the lithosphere beneath the central Slave craton. Commonly observed discontinuities at $410-$ and $670-\mathrm{km}$ depths appear sensitive to the thermal state of the mantle and may thus provide clues to kimberlite eruption processes. These various new results from the central Slave craton can also be compared and contrasted with similar studies and their recently published results from the Kaapvaal, Siberia and western Australia (Kennett et al., 1994; Debayle and Kennett, 2000; James et al., 2001; Oreshin et 
al., 2002; Simon et al., 2002). Meanwhile isolated stations will be installed within other major cratons of North America.

\section{REFERENCES}

Bank, C.-G., Bostock, M.G., Ellis, R.M., Cassidy, J.F., 2000. A reconnaissance teleseismic study of the upper mantle and transition zone beneath the Archean Slave craton in NW Canada. Tectonophysics 319, 151-166.

Bostock, M. G., 1998. Seismic stratigraphy and evolution of the Slave province. J. Geophys. Res. 103, 21183-21200.

Bostock, M. G., 1999. Seismic imaging of lithospheric discontinuities and continental evolution. Lithos 48, 116 .

Debayle, E., Kennett, B. L. N., 2000. Anisotropy in the Australian upper mantle from Love and Rayleigh waveform inversion. Earth Planet. Sci. Lett. 184, 339351.

Griffin, W. L., Doyle, B. J., Ryan, C. G., Pearson, N. J., O’Reilly, S. Y., Davies, R. M., Kivi, K., van Achterbergh, E., Natapov, L. M., 1999. Layered mantle lithosphere in the Lac de Gras area, Slave Craton: composition, structure, and origin. J. Petrology 40, 705-727.

Hales, A.L., 1969. A seismic discontinuity in the lithosphere. Earth Planet. Sci. Lett. 7, 44-46.

James, D.E., Fouch, M.J., VanDecar, J.C., van der Lee, S., Kaapvaal Seismic Group, 2001. Tectosphere structure beneath southern Africa. Geophys. Res. Lett. 28, 2485-2488.

Jones, A. G., Ferguson, I. J., Chave, A. D., Evans, R. L., McNeice, G. W., 2001. Electric lithosphere of the Slave craton. Geology, 29, 423-426.

Kennett, B.L.N., Gudmunsson, O., Tong, C., 1994. The upper mantle $\mathrm{S}$ and $\mathrm{P}$ velocity structure beneath northern Australia from broadband observations. Phys. Earth Planet. Inter. 86, 85-98.

Kopylova, M. G., Russell, J. K., 2000. Chemical stratification of cratonic lithosphere: constraints from the northern Slave craton, Canada. Earth Planet. Sci. Lett.181, 7187.

Lehman, I., 1955. The times of $\mathrm{P}$ and $\mathrm{S}$ in northeastern America. Ann. Geofis. 8, 351-370.

Nolet, G., Grand, S.P., Kennett, B.L.N., 1994. Seismic heterogeneity in the upper mantle. J. Geophys. Res. 99, 23753-23766.

Oreshin, S., Vinnik, L., Makeyeva, L., Kosarev, G., Kind, R., Wentzel, F., 2002. Combined analysis of SKS splitting and regional P traveltimes in Siberia. Geophys. J. Int. $151,393-402$.

Rümpker, G., Silver, P. G., 1998. Apparent shear-wave splitting parameters in the presence of vertically varying anisotropy. Geophys. J. Int. 135, 790-800.

Savage, M. K., 1999. Seismic anisotropy and mantle deformation: what have we learned from shear wave splitting. Rev. Geophysics 37, 65-106.

Silver, P. G., 1996. Seismic anisotropy beneath the continents: Probing the depths of geology. Ann. Rev. Earth Planet. Sci. 24, 385-432.

Simon, R. E., Wright, C., Kgaswane, E.M., Kwadiba, M.T.O., 2002. The $P$ wavespeed structure below and around the Kaapvaal craton to depths of $800 \mathrm{~km}$, from traveltimes and waveforms of local and regional earthquakes and mining-induced tremors. Geophys. J. Int. 151, 132-145.

Vinnik, L. P., Makayeva, L. I., Milev, A., Usenko, A. Y., 1992. Global patterns of azimuthal anisotropy and deformations in the continental mantle. Geophys. J. Int. $111433-447$.

Contact: DB Snyder, Geological Survey of Canada, 615 Booth Street, Ottawa, ON K1A 0E9, Canada. E-mail: dsnyder@nrcan.gc.ca 


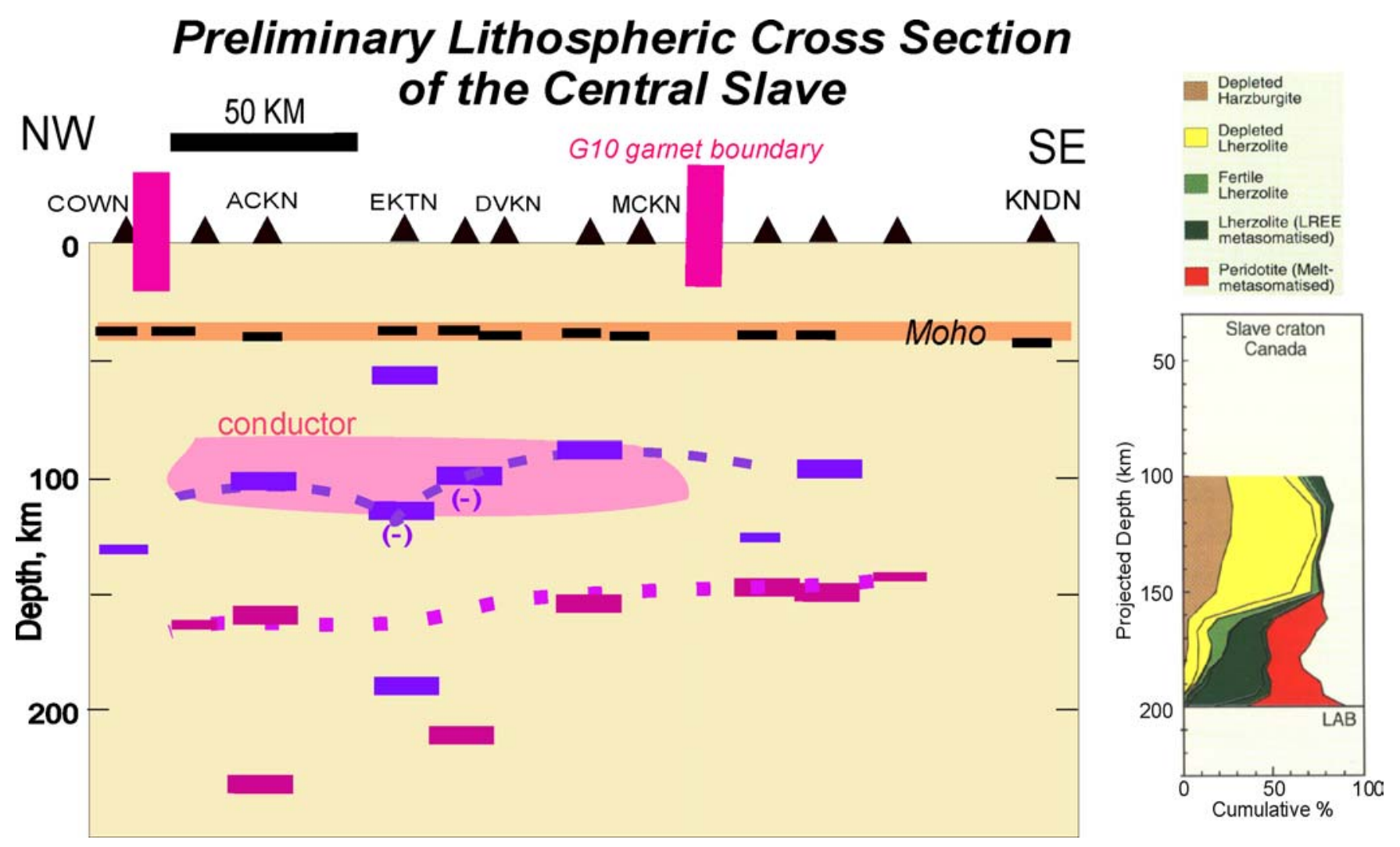

Figure 1. Discontinuities beneath the central Slave craton. Seismic stations labeled are located at: Kennady Lake (KNDN), NE McKay Lake (MCKN), the Diavik mine airstrip (DVKN), the Ekati mine airstrip (EKTN), Achilles Lake (ACKN) and SW of Contwoyto Lake $(\mathrm{COWN})$. Blue and red bars represent discontinuities identified beneath individual stations with opposing polarities on each transverse component. Smaller bars indicate less reliable estimates. Petrologic column from Griffin et al. (1999); conductor from Jones et al. (2001). 